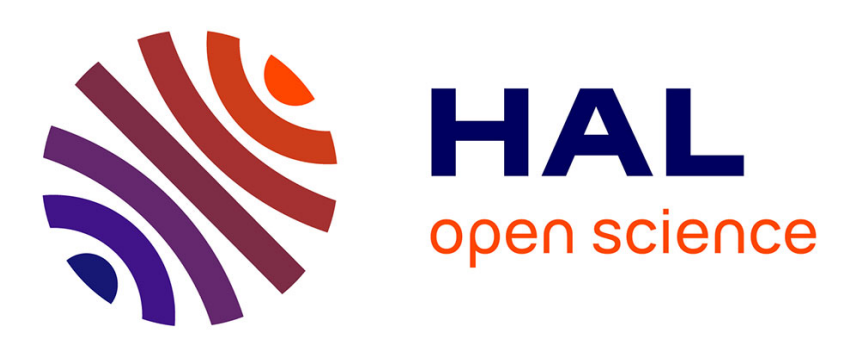

\title{
Is the bumblebee (Bombus haemorrhoidalis) the only pollinator of large cardamom in central Himalayas, India?
}

\author{
Palatty Sinu, Giby Kuriakose, K. Shivanna
}

\section{- To cite this version:}

Palatty Sinu, Giby Kuriakose, K. Shivanna. Is the bumblebee (Bombus haemorrhoidalis) the only pollinator of large cardamom in central Himalayas, India?. Apidologie, 2011, 42 (6), pp.690-695. 10.1007/s13592-011-0065-1 . hal-01003601

\section{HAL Id: hal-01003601 \\ https://hal.science/hal-01003601}

Submitted on 1 Jan 2011

HAL is a multi-disciplinary open access archive for the deposit and dissemination of scientific research documents, whether they are published or not. The documents may come from teaching and research institutions in France or abroad, or from public or private research centers.
L'archive ouverte pluridisciplinaire HAL, est destinée au dépôt et à la diffusion de documents scientifiques de niveau recherche, publiés ou non, émanant des établissements d'enseignement et de recherche français ou étrangers, des laboratoires publics ou privés. 


\title{
Is the bumblebee (Bombus haemorrhoidalis) the only pollinator of large cardamom in central Himalayas, India?
}

\author{
Palatty Allesh Sinu, Giby Kuriakose, and K. R. Shivanna \\ Ashoka Trust for Research in Ecology and the Environment, Royal Enclave, Srirampura, Jakkur Post, \\ Bangalore 560 064, India
}

Received 25 October 2010 - Revised 15 February 2011 - Accepted 16 February 2011

\begin{abstract}
Amomum subulatum (Zingiberaceae) is one of the major cash crops of the Eastern Himalayas. Our earlier study had shown that Bombus haemorrhoidalis is the only pollinator of A. subulatum. This was surprising in light of findings that other members of Zingiberaceae have at least a few pollinators for each plant species. We hypothesized that $A$. subulatum also is a generalist. Studies were carried out in six plantations of Northeast India. Floral visitors and their frequency were recorded. The pollination efficiency of each visitor was determined on the basis of pollen transfer to the stigma following a single visit of the pollinator to virgin flower. B. haemorrhoidalis, Apis cerana, Megachile lanata, Episyrphus balteatus (hover fly), Macroglossum stellatarum (hawk moth), and Aethopyga siparaja (crimson sunbird) visited the flowers of A. subulatum. Of these, B. haemorrhoidalis, M. lanata, and A. siparaja were effective pollinators. B. haemorrhoidalis was an important pollinator across all the plantations. Flower opening pattern influenced the pollination efficiency of visitors.
\end{abstract}

Amomum subulatum / bumblebee / pollination efficiency / pollen robber / Eastern Himalayas / Zingiberaceae

\section{INTRODUCTION}

The large cardamom (Amomum subulatum Roxb., Zingiberaceae) is one of the major cash crops (important spice) cultivated between elevations of 500 and $2,000 \mathrm{~m}$ in tropical wet evergreen forests of the Eastern Himalayas of India (Sikkim and Darjeeling areas), Nepal, and Bhutan. As the fruits and seeds are the economic products, effective pollination is a prerequisite for fruit and seed set and, to a large extent, determines the yield. In an earlier study, based on one plantation, we reported that Bombus haemorrhoidalis and Apis cerana are

Corresponding author: P.A. Sinu, sinu@atree.org Manuscript editor: Klaus Hartfelder the only floral visitors of large cardamom; the former is the effective pollinator while the latter is a pollen robber (Sinu and Shivanna 2007a).

There has been considerable discussion in recent years concerning the concept of generalization and specialization in plant-pollinator interactions (Waser et al. 1996; Waser and Ollerton 2006; Mitchell et al. 2009). Generalists attract a number of animal species for pollination, whereas specialists use a few or just one animal species for pollination. The concept represents two ends of a continuum between extreme generalization and obligate specialization (Waser 2006). Obligate specialization, in which the plant species depends on a single pollinator and shows reciprocal specialization between plant and pollinator, is found only in a limited number of taxa such as figs, yuccas, and 
some orchids. Otherwise, most plant species use varying numbers of animal species for pollination services. Members of Zingiberaceae studied so far also have at least a few pollinators for each plant species (Sakai et al. 1999; Sinu and Shivanna 2007b; Kuriakose et al. 2009).

In light of these findings, it was rather surprising that $B$. haemorrhoidalis is the only pollinator of $A$. subulatum, also a member of Zingiberaceae. We hypothesized that A. subulatum also has more than one pollinator. As our earlier study was confined to just one plantation, it was necessary to extend the studies to other locations. Our focus was on the following questions: (1) Are there any other pollinators for A. subulatum? (2) If so, what is their pollination efficiency?

\section{MATERIALS AND METHODS}

Studies were carried out in six A. subulatum plantations in the adjoining Sikkim and Darjeeling hills of India during the peak of the flowering season (May and June) in 2007. Except one location (Sanghola, $523 \mathrm{~m}$ a.s.1.), all the other studied plantations were located above $1,200 \mathrm{~m}$ a.s.l. A drought-resistant cultivar "Jungu" is grown in this low-elevation plantation. In all other plantations, the cultivar "Sowney" is grown (information from Spices Board, Sikkim). The visitation frequency of all the major visitors to $A$. subulatum flowers was studied by recording the visitors in selected numbers of flowers (a total of 184 flowers, see Table I for details) uninterruptedly for $4-6 \mathrm{~h}$ from 0500 hours, beginning of the visitation. A total of 11 days were spent on recording the visits to A. subulatum flowers. Visitation frequency is represented by the number of visits per flower per hour. We made an attempt to estimate the number of flowers a bumblebee visits in a foraging bout by following the bee $(n=128$ bumblebees) from its entry into the plantation until it left. After each bout of foraging, the bumblebee flies away from A. subulatum plants to brush off the pollen trapped on the thoracic surface of its body.

To study the pollination efficiency of each visitor species, only the focal visitor species was allowed to visit the flowers in the observation patch from the time of flower opening until 1200 hours; other visitors were chased away to prevent them from visiting the target flowers. The observed flowers were covered using a paper bag in the previous day. At the end of the observation period, the flowers (a total of 2,358 flowers, see Table II for details) visited by specific pollinators were excised and their stigmas observed under the microscope to record the presence of pollen. To study the pollination efficiency under open field conditions, four flowers each from 36 randomly selected plant clumps from each plantation were excised at 1200 hours and checked for pollen transfer to the stigma.

Data on the pollination efficiency in open-pollinated flowers among plantations were analyzed by one-way ANOVA. Arcsine-square root-transformed data of percentage pollinated flowers were used for the comparisons. Mean and standard error $( \pm \mathrm{SEM})$ are given in the text.

Flowering at low elevation commences about a month earlier (mid-March-April) than at higher elevations (late May onwards). The flower remains fresh just for 1 day. The details of floral morphology and phenology of $A$. subulatum are described by Sinu and Shivanna (2007a). The flowers offer both pollen and nectar as rewards for visitors.

\section{RESULTS}

We recorded as many as six visitor species to A. subulatum flowers-B. haemorrhoidalis (bumblebee, Apidae: Hymenoptera), A. cerana (honeybee, Apidae: Hymenoptera), Megachile lanata (Megachilidae: Hyemenoptera), Episyrphus balteatus (hover fly, Syrphidae: Diptera), Macroglossum stellatarum (hawk moth, Sphingidae: Lepidoptera), and Aethopyga siparaja (crimson sunbird; Aves: Nectariniidae). B. haemorrhoidalis was the only common visitor species across all the studied plantations (Table I). A. cerana visited the flowers only in one plantation in which beehives were maintained. M. lanata visited flowers in higher frequency at one plantation (Sanghola) located at lower elevation and in very low frequency at two other plantations at higher elevations (Table I). A. siparaja visited the flowers only in one plantation raised as an agroforestry system located in a wildlife sanctuary (WLS). 
Table I. Visitation frequency (number of visits per flower per hour) of pollinator species to A. subulatum flowers in different plantations.

\begin{tabular}{|c|c|c|c|c|c|c|c|}
\hline $\begin{array}{l}\text { Location of } \\
\text { plantation }\end{array}$ & $\begin{array}{l}\text { Geographical } \\
\text { coordinates }\end{array}$ & $\begin{array}{l}\text { No. of } \\
\text { flowers }\end{array}$ & $\begin{array}{l}\text { Bombus } \\
\text { haemorrhoidalis }\end{array}$ & $\begin{array}{l}\text { Apis } \\
\text { cerana }\end{array}$ & $\begin{array}{l}\text { Megachile } \\
\text { lanata }\end{array}$ & $\begin{array}{l}\text { Aethopyga } \\
\text { siparaja }\end{array}$ & $\begin{array}{l}\text { Overall } \\
\text { frequency }\end{array}$ \\
\hline Assam Lingsey & $\begin{array}{l}27^{\circ} 17.009^{\prime} \mathrm{N} \\
88^{\circ} 37.448^{\prime} \mathrm{E}\end{array}$ & 51 & 0.222 & 0.402 & & & 0.624 \\
\hline Kalihola & $\begin{array}{l}27^{\circ} 00.233^{\prime} \mathrm{N} \\
88^{\circ} 18.233^{\prime} \mathrm{E}\end{array}$ & 60 & 0.120 & & 0.033 & 0.103 & 0.137 \\
\hline Lingdoh & $\begin{array}{l}22^{\circ} 22.446^{\prime} \mathrm{N} \\
888^{\circ} 34.482^{\prime} \mathrm{E}\end{array}$ & 10 & 0.250 & & & & 0.250 \\
\hline Lower Lingdoh & $\begin{array}{l}27^{\circ} 23.188^{\prime} \mathrm{N} \\
88^{\circ} 35.070^{\prime} \mathrm{E}\end{array}$ & 20 & 0.444 & & 0.025 & & 0.469 \\
\hline Rampuria & $\begin{array}{l}27^{\circ} 00.523^{\prime} \mathrm{N} \\
88^{\circ} 18.546^{\prime} \mathrm{E}\end{array}$ & 22 & 0.059 & & & & 0.059 \\
\hline Sanghola & $\begin{array}{l}27^{\circ} 00.233^{\prime} \mathrm{N} \\
88^{\circ} 18.233^{\prime} \mathrm{E}\end{array}$ & 21 & 0.038 & & 0.481 & & 0.519 \\
\hline
\end{tabular}

Visits of M. stellatarum and E. balteatus were rare and were observed only in Rampuria (Darjeeling hills). The visitation frequency of individual visitor species in different plantations is summarized in Table I. When the visitation frequency of all the visitors was pooled among plantations, we found that A. subulatum flower received an average of $0.34 \pm 0.09$ visits per flower per hour (range, $0.05-0.62$ visits; $n=184$ ). $B$. haemorrhoidalis made an average of $0.19 \pm$ 0.06 visits per flower per hour (range, $0.04-0.44$

Table II. Pollination efficiency of each pollinator species in terms of pollen transfer to stigma.

\begin{tabular}{ll}
\hline Pollination type & $\%$ of pollinated \\
& flowers $(n)$
\end{tabular}

\begin{tabular}{lr}
\hline Apis cerana & $0(124)$ \\
Bombus haemorrhoidalis & $83.09(633)$ \\
Queen & $100(194)$ \\
Worker & $75.62(439)$ \\
Episyrphus balteatus & $0(22)$ \\
Megachile lanata & $34.8(23)$ \\
Macroglossum stellatarum & $0(12)$ \\
Aethopyga siparaja & $74(27)$ \\
Open pollination & $35.96(864)$
\end{tabular}

$n$ in parentheses denotes the number of flowers studied for each visitor visits; $n=184)$. In honeybee-visited plantation, A. cerana made $0.40 \pm 0.34$ visits per flower per hour (range, $0.12-0.81$ visits; $n=51$ ). M. lanata made an average of $0.18 \pm 0.10$ visits per flower per hour (range, $0.03-0.48$ visits; $n=91$ ).

The pollination efficiency of each pollinator is presented in Table II. An interesting feature of the flowers of $A$. subulatum is that the length of the gap between labellum and anther-stigma column of flowers increases across the day (Figure 1, and refer Sinu and Shivanna 2007a for more details) from $0.46 \mathrm{~cm}$ in early morning hours (0400-0700 hours) to $0.9 \mathrm{~cm}$ by 1100 hours, and to $2 \mathrm{~cm}$ by $1500-1600$ hours $(n=49)$. The extent of the gap is inversely related to the pollination efficiency; as the gap increases, the bee's body does not come in contact with the anther-stigma column and thus pollination does not occur (Figure 1).

B. haemorrhoidalis visited A. subulatum flowers primarily for nectar. While harvesting nectar, their thoracic pubescence traps a large number of pollen grains from the anther-stigma column located above the entry point of the bumblebee (Sinu and Shivanna 2007a). When a bumblebee with a pollen-laden thorax visits flowers, it brings about pollination.

After visiting several flowers, a bumblebee leaves the plantation to brush off the pollen from the thoracic surface using its middle legs. 

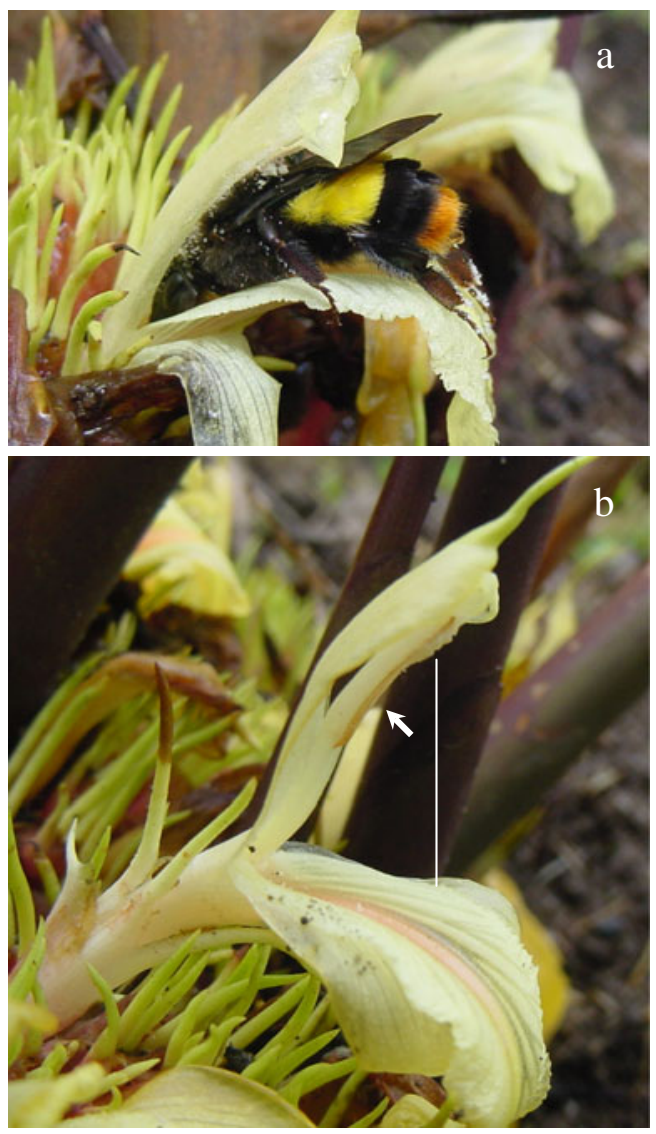

Figure 1. a Worker bumblebee foraging nectar from an $A$. subulatum flower in the early hours of the day; white pollen is seen on the thorax of the bee. b Flower of A. subulatum photographed at 1400 hours to show the increase in the length of the gap (indicated by the line) between the anther-stigma column (top portion) and the labellum (bottom portion). Partially pollen-removed anther column is indicated by an arrow.

When we followed individual bumblebees $(n=$ 128 ) in plantations, we found that a bee visited an average of $34.5 \pm 10.4$ flowers in a foraging bout before exiting the spot; no more than one visit was made to an individual flower in a visiting bout, and the average time spent per flower was $20.6 \mathrm{~s}( \pm 0.26 ; n=2,702)$. An average of $83.09 \%$ ( $n=633$ flowers, six plantations) of the bumblebee-visited flowers were pollinated (Table II). When we examined the efficiency of different castes of bumblebees (queen and worker), we found that $100 \%$ ( $n=194$ flowers) of the large-bodied queen-visited flowers were pollinated. Queen bumblebee visitation frequency, however, was very low in the plantations, and it happened mostly before 0900 hours. The overall pollination efficiency due to the visits of relatively smaller sized worker bumblebee (dominant bumblebee caste in the plantations) was $75.62 \%$ ( $n=439$ flowers). The pollination efficiency of worker bumblebees across the day was $100 \%$ (0400-0600 hours, $n=4$ flowers), 94\% (0600-0800 hours, $n=70$ flowers), $79 \%$ (0800-1,000 hours, $n=169$ flowers), and 18\% (1000-1200 hours, $n=34$ flowers). A. cerana was a "pollen robber"; it did not collect nectar and did not transfer pollen to the stigma (pollination efficiency was $0 \%, n=124$ flowers). The nectar-collecting solitary $M$. lanata bee pollinated $34.8 \%$ of the flowers ( $n=23$ flowers). The pollination efficiency in sunbird-visited flowers was $74 \%$ ( $n=27$ flowers). The pollination efficiency of $M$. stellatarum $(n=12)$ and E. balteatus $(n=22)$ was zero. The overall pollination efficiency under open field conditions was $35.96 \%$ ( $n=864$ flowers from six plantations). The percentage of the pollinated flowers was not significantly different among plantations (one-way ANOVA, $F_{4,7}=0.88, P=0.52$ ).

\section{DISCUSSION}

The present study, covering as many as six plantations, has shown that although the bumblebee, $B$. haemorrhoidalis, is the most important and common pollinator species of $A$. subulatum across the plantations in the Central Himalayas of India, two other pollinators-a solitary bee, $M$. lanata, and a sunbird speciesare also effective pollinators. $M$. lanata and $A$. siparaja show spatial variation. $M$. lanata was a frequent floral visitor in low-elevation plantations, whereas $B$. haemorrhoidalis was only an occasional visitor. In high-elevation plantations, however, it was the other way round; $M$. lanata was an infrequent floral visitor relative to $B$. haemorrhoidalis. Obviously, variation in the local habitats and the availability of pollinator 
species would determine the pollinator guild of the species in different plantations (Klein et al. 2003; Kuriakose et al. 2009).

The pollination efficiency of $M$. lanata was markedly lower (34.8\%) when compared with that of bumblebee visits $(83.09 \%)$. This appears to be due to the smaller size of the M. lanata; unless it visits the flowers early in the morning, the body of this species is unlikely to come in contact with the anther and stigma column of the flower.

The sunbird was present in an agroforestry system that is raised under the canopy of wild forest trees in Senchal WLS. Its pollination efficiency was $74 \%$. The sunbird was absent in all other plantations that are raised under the shade of Alnus nepalensis (Himalayan alder). An interesting feature is that all the three pollinators of $A$. subulatum are nectar foragers. The present study clearly shows that $A$. subulatum is also a generalist, as reported in other members of Zingiberaceae, with three effective pollinators. It also highlights the need to study the pollination biology of a species at different locations for a clear understanding of pollinators. A comparison of the pollinator efficiency of bumblebee-visited flowers $(83.09 \%)$ and open pollination $(35.96 \%)$ clearly indicates that pollinator limitation can be the primary reason for low fruit set in $A$. subulatum in the Indian Himalayas.

The worldwide decline in the population of pollinators (Vamosi et al. 2006) and the deterioration in the quality of habitats (Ricketts 2004) are of global concern particularly in sustaining the productivity of several crop species (Kearns et al. 1998). Further studies should address the question of how A. subulatum plantations and agroforestry systems can be managed at local and landscape levels in order to increase habitat quality for important pollinators to improve pollination efficiency. An earlier preliminary report on $A$. subulatum in the Himalayas has implicated honeybees as the pollinators on the basis of an increase in yield in the presence of honeybee hives in the plantation (Verma 1987). Our earlier studies (Sinu and Shivanna 2007a) and the present study in several plantations of $A$. subulatum clearly show that $A$. cerana is a non- mutualistic floral visitor and does not bring about pollination. Studies on another related species belonging to Zingiberaceae, Eletteria cordamomum (cardamom of commerce), with the same basic floral architecture as $A$. subulatum (Sinu and Shivanna 2007b; Kuriakose et al. 2009), have shown that E. cardamomum is a generalist with as many as five species of insects (smaller bees such as Trigona and Apis, larger bees such as Xylocopa) and two species of birds as effective pollinators. The pollination system in $A$. subulatum can be considered as more specialized when compared with $E$. cardamomum, with fewer pollinators. Larger flowers and longer corolla tube in A. subulatum permits insects with longer proboscis such as $B$. haemorrhoidalis and Megachile sp., and birds to harvest nectar and effect pollination. Smaller bees are eliminated from nectar foraging.

\section{ACKNOWLEDGEMENTS}

This work was supported by the Department of Science and Technology, Government of India. We thank all the farmers for their cooperation.

Bombus haemorrhoidalis: unique pollinisateur de la cardamone brune dans le centre de l'Hymalaya indien?

Amomum subulatum / bourdon / efficacité pollinisatrice / vol de pollen / Hymalaya oriental / Zingiberaceae

Ist die Hummel Bombus haemorrhoidalis der einzige Bestäuber des schwarzen Cardamons im zentralen Himalaya, Indien?

Amomum subulatum / Hummel / Bestäubungsleistung / Pollenräuber / Ost-Himalaya / Zingiberaceae

\section{REFERENCES}

Kearns, C., Inouye, D., Waser, N. (1998) Endangered mutualisms: the conservation of plant-pollinator interactions. Annu. Rev. Ecol. Syst. 29, 83-112 
Klein, A.-M., Steffan-Dewenter, I., Tscharntke, T. (2003) Pollination of Coffea canephora in relation to local and regional agroforestry management. J. Appl. Ecol. 40, 837-845

Kuriakose, G., Sinu, P.A., Shivanna, K.R. (2009) Domestication of cardamom (Elettaria cardamomum) in Western Ghats, India: divergence in productive traits and a shift in major pollinators. Ann. Bot. 103, 727-733

Mitchell, R.J., Irwin, R.E., Flanagan, R.J., Karron, J.D. (2009) Ecology and evolution of plant-pollinator interactions. Ann. Bot. 103, 1355-1363

Ricketts, T.H. (2004) Tropical forest fragments enhance pollinator activity in nearby coffee crops. Conserv. Biol. 18, 1262-1271

Sakai, S., Kato, M., Inouye, T. (1999) Three pollination guilds and variation in floral characteristics of Bornean gingers (Zingiberaceae and Costaceae). Am. J. Bot. 86, 646-658

Sinu, P.A., Shivanna, K.R. (2007a) Pollination biology of large cardamom (Amomum subulatum). Curr. Sci. 93, 548-552
Sinu, P.A., Shivanna, K.R. (2007b) Pollination ecology of cardamom (Elettaria cardamomum) in Western Ghats. India. J. Trop. Ecol. 23, 493-496

Vamosi, J.C., Knight, T.M., Steets, J.A., Mazer, S.J., Burd, M., Ashman, T. (2006) Pollination decays in biodiversity hotspots. Proc. Natl. Acad. Sci. U.S.A. 103, 956-961

Verma, K.S. (1987) Preliminary studies on the effect of honey bees on the yield of greater cardamom. Ind. Bee J. 49, 25-26

Waser, N.M. (2006) Specialization and generalization in plant-pollinator interaction: a historical perspective. In: Waser, N.M., Ollerton, J. (eds.) Plant-pollinator interactions: from specialization to generalization, pp. 3-17. The University of Chicago Press, Chicago

Waser, N.M., Ollerton, J. (2006) Plant-pollinator interactions: from specialization to generalization. The University of Chicago Press, Chicago

Waser, N.M., Chittka, L., Price, M.V. (1996) Generalization in pollination systems, and why it matters. Ecology 77, 1043-1060 